\title{
STRATEGI PENGELOLAAN KELAS UNGGULAN DALAM MENINGKATKAN PRESTASI BELAJAR SISWA
}

\author{
Amalia Ratna Zakiah Wati \\ Syunu Trihantoyo \\ Jurusan Manajemen Pendidikan, Fakultas IImu Pendidikan, Universitas Negeri Surabaya \\ E-mail : amaliaratnazw@gmail.com
}

\begin{abstract}
This research aims to describe and analyze the data about the pre-eminent Class management strategies in improving student learning Achievements, factor endowments and restricting factors in Winning Class in management strategies Improve student learning, Achievement and the solution of resistance occurring in the Superior Class management strategies in improving the Learning Achievements of students in 2281 Turi Lamongan. This research uses qualitative type of approach. Data collection is done using interviews, observation, and study the documentation. Test the validity of the data is done through a test of the credibility of the data include triangulation and membercheck. The next Test was done transferability test and dependability test. Technique of data analysis is performed by means of collecting data, the condensation of data, presents data, as well as verification and assertion inference. Research Results Strategy Management of superior classes in improving learning achievement Strategy is needed. Turi Lamongan 1 Public Middle School has several strategies namely Building Collaboration with Students in Learning, Creating a Conducive Learning Climate, Evaluating the Teaching and Learning Process. In the classroom management strategy there are factors that support, among others: curriculum factors, facilities, teachers, students, families. In class management strategies there will be obstacles, these obstacles can come from the teacher himself, from students, family environment or due to facilities. Solutions in overcoming obstacles in managing superior classes in improving student learning achievement by maximizing the program. If the inhibiting factors are from the family, students need to be guided from the family and need a high awareness of the students about their rights and obligations.
\end{abstract}

Keywords: classroom management strategies, learning achievements, students

\begin{abstract}
Abstrak : Penelitian ini bertujuan untuk mendeskripsikan dan menganalisis data tentang Strategi Pengelolaan Kelas Unggulan Dalam Meningkatkan Prestasi Belajar Siswa, faktor pendukung dan faktor penghambat dalam Strategi Pengelolaan Kelas Unggulan Dalam Meningkatkan Prestasi Belajar Siswa, dan Solusi dari hambatan yang terjadi dalam Strategi Pengelolaan Kelas Unggulan Dalam Meningkatkan Prestasi Belajar Siswa di SMPN 1 Turi Lamongan. Penelitian ini menggunakan jenis pendekatan kualitatif. Pengumpulan data dilakukan dengan menggunakan teknik wawancara, observasi, dan studi dokumentasi. Uji keabsahan data dilakukan melalui uji kredibilitas data yang meliputi triangulasi dan membercheck. Selanjutnya dilakukan Uji transferabilitas dan Uji dependabilitas. Teknik analisis data dilakukan dengan cara mengumpulkan data, kondensasi data, menyajikan data, serta verifikasi dan penegasan kesimpulan. Hasil penelitian Strategi pengelolaan kelas unggulan dalam meningkatkan prestasi belajar, maka diperlukan sebuah adanya strategi. SMPN 1 Turi Lamongan memiliki beberapa strategi untuk pengelolaan kelas unggulan dalam meningkatkan prestasi belajar siswa yaitu Membangun Kerjasama dengan Siswa dalam Pembelajaran, Menciptakan Iklim Pembelajaran yang Kondusif, Evaluasi Proses Belajar Mengajar. Dalam strategi pengelolaan kelas ada faktor yang mendukung antara lain: faktor kurikulum, sarana, guru, siswa,keluarga. Dalam strategi pengelolaan kelas akan ditemui berbagai faktor penghambat. Hambatan tersebut bisa datang dari guru sendiri, dari peserta didik, lingkungan keluarga ataupun karena faktor fasilitas. Solusi dalam mengatasi hambatan strategi pengelolaan kelas unggulan dalam meningkatkan prestasi belajar siswa adalah dengan cara memaksimalkan programnya,dan apabila ada faktor penghambat dari keluarga maka siswa perlu dibimbing dari keluarga, dan diperlukan kesadaran yang tinggi dari siswa akan hak dan kewajibannya.
\end{abstract}

Kata kunci : strategi pengelolaan kelas, prestasi belajar, siswa 
Salah satu aspek penting dalam kehidupan manusia yaitu pendidikan. Dengan mendapatkan pendidikan, seseorang akan bisa mengeluarkan semua potensi dan juga bakat yang ada didalam dirinya sehingga dapat semakin dikembangkan. Dalam satu cara atau yang lain tampaknya semua ras manusia, meskipun selama perjalanan waktu, makna dan tujuannya telah pasti mengalami perubahan tertentu. Memahami konsep pendidikan dan fitur dinamisnya akan membantu guru mengembangkan wawasan tentang tujuan menjadi guru dan membantu guru saat mendidik siswa.

Fungsi paling pokok dari pendidikan adalah untuk mempersiapkan bekal bagi generasi selanjutnya supaya dapat mempunyai kapasitas, pengetahuan dan keahlian yang mumpuni untuk bisa menghadapi perkembangan zaman global ini. Beberapa orang menyebut pendidikan sebagai sekolah formal atau pembelajaran seumur hidup. Beberapa yang lain menyebutnya sebagai perolehan pengetahuan, keterampilan, dan sikap. Beberapa mengatakan bahwa pendidikan bukanlah apa-apa, tetapi melatih pikiran orang dalam arah tertentu untuk menghasilkan perubahan yang diinginkan. Tujuan pendidikan tidak dapat semata-mata untuk menciptakan individu yang melek huruf, atau orang yang sangat berpengetahuan penuh dengan informasi dan fakta, atau untuk menciptakan individu untuk mencari pekerjaan.

Perubahan era globalisasi yang diindikasikan dengan berkembangnya berbagai cabang ilmu pengetahuan dan juga teknologi dengan sangat pesat dari berbagai bidang. Banyaknya ketersediaan tenaga kerja dan juga lulusan dari sekolah dan perguruan tinggi menuntut sumber daya manusia yang berkualitas yang dengan demikian menciptakan tingkat persaingan yang semakin tinggi dan kompetitif.

Banyak lembaga pendidikan yang berusaha meningkatkan kualitas pendidikan yang diberikan kepada siswa dalam rangka memperbaiki kualitas dan Sumber Daya Manusia dalam dunia pendidikan. Karena alasan itulah muncul berbagai model sekolah yang mempunyai karakteristik khusus yang menjadi ciri khas sekolah tersebut. Misalnya ada Sekolah Nasional Bertaraf Internasional, Sekolah Plus, Sekolah Terpadu, dan Sekolah
Unggulan. Sekolah-sekolah ini menyediakan berbagai program yang menarik dan berkualitas yang pada prinsipnya bertujuan untuk meningkatkan dan memajukan pendidikan di daerahnya.

Kegiatan belajar mengajar merupakan interaksi timbal balik dari guru dan juga siswa. Ada dampak dari kegiatan belajar terhadap perkembangan dan pola pikir siswa. Oleh karena itu ada proses saling mempengaruhi baik secara aktif dan pasif. Di dalam kelas yang pasif dan aktif, disiplin atau tidak disiplin guru akan berlaku berbeda. Disamping itu siswa tidak hanya berinteraksi dengan guru, namun juga dengan siswa lainnya dan juga sumber daya (orang lain yang juga menyediakan informasi baik secara langsung maupun tidak langsung). Didalam proses belajar dan mengajar, guru membutuhkan siswa dan siswa membutuhkan guru agar bisa berjalan dengan baik. Sebaliknya dengan kegiatan belajar, guru tidak perlu berada didekat siswa, tapi siswa tetap bisa belajar sendiri (Syaodih, 2003:31).

Tujuan pengajaran akan bisa dicapai jika guru mampu mengatur dan mengelola kelas sehingga menghasilkan kondisi belajar yang membantu siswa belajar dengan baik. Strategi pembelajaran adalah langkah yang diambil peserta didik untuk meningkatkan pembelajaran mereka. Penggunaan aktif strategi bahasa pembelajaran membantu peserta didik mengendalikan pembelajaran mereka sendiri dengan mengembangkan keterampilan bahasa, meningkatkan kepercayaan diri dan motivasi dalam proses pembelajaran. Instruksi strategi meningkatkan pembelajaran mandiri siswa dan pembelajaran mandiri dan membantu peserta didik untuk bertanggung jawab atas pembelajaran mereka sendiri. Semakin banyak strategi yang digunakan pelajar, semakin banyak pelajar merasa percaya diri, termotivasi dan berkhasiat. Guru didorong untuk memilih teknik pengajaran yang tepat dan strategi pembelajaran untuk siswa dan mengajar mereka bagaimana memahami strategi belajar untuk meningkatkan tingkat pembelajaran mandiri. Agar bisa mencapai tujuan tersebut maka diperlukan manajemen atau pengelolaan kelas yang efektif dan efisien. Manajemen kelas yang efektif adalah persyaratan untuk pendidikan yang efektif.

Manajemen kelas yang efektif umumnya didasarkan pada prinsip membangun 
lingkungan kelas yang positif yang mencakup hubungan guru-siswa yang efektif (Wubbels et al., 1999). Evertson dan Weinstein (2006:11) mendefinisikan manajemen kelas sebagai "tindakan yang dilakukan guru untuk menciptakan lingkungan yang mendukung dan memfasilitasi pembelajaran akademik dan sosial-emosional". Definisi ini berkonsentrasi pada tanggung jawab guru dalam penggunaan strategi manajemen kelas dengan berbagai tujuan pembelajaran bagi siswa.

Evertson dan Weinstein (2006:11) merujuk dalam definisi mereka tentang manajemen kelas dengan tindakan yang diambil guru untuk menciptakan lingkungan yang mendukung pembelajaran akademik dan sosial emosional siswa. Mereka menggambarkan lima jenis tindakan. Untuk mencapai manajemen kelas yang berkualitas tinggi, guru harus (1) mengembangkan hubungan peduli dan suportif dengan dan di antara siswa dan (2) mengatur dan menerapkan instruksi dengan cara mengoptimalkan akses siswa untuk belajar. Pentingnya mengembangkan hubungan gurusiswa yang baik juga dijelaskan Marzano et al. (2003). Selain itu, Evertson dan Weinstein (2006) menyatakan bahwa guru harus (3) mendorong keterlibatan siswa dalam tugas akademik. Dapat dilakukan dengan menggunakan metode manajemen kelompok (misalnya, dengan menetapkan aturan dan prosedur kelas (Marzano et al., 2003)

Dengan begitu banyaknya anak-anak bangsa yang berpotensi, maka pendidikan unggulan merupakan sebuah kebutuhan yang memerlukan perhatian khusus. Setiap siswa mempunyai potensi yang berbeda oleh karena itu memerlukan bimbingan dan pengajaran yang berbeda pula. Anak yang unggul dan berpotensi harus mendapatkan pengajaran yang sesuai dengan kemampuannya sehingga ia menjadi lebih unggul dan bisa mencapai tingkatan prestasi semaksimal mungkin. Di dalam kelas unggulan, siswa akan mendapatkan pelajaran secara intensif.

SMP Negeri 1 Turi Lamongan adalah contoh sekolah unggulan yang berlokasi di kecamatan Turi kabupaten Lamongan. Sekolah ini memiliki kelas unggulan sejak tahun akademi 2011/2012 dengan tujuan agar siswa-siswa yang termasuk unggul bisa ditingkatkan kemampuannya baik secara kognitif, psikomotorik dan juga afektif.
Berbagai program didesain untuk mendorong siswa mengeluarkan kemampuannya semaksimal mungkin dan meningkatkan prestasinya. Untuk menciptakan siswa berprestasi dan unggul maka sekolah harus mempunyai strategi yang efektif dan efisien serta terkoordinir dengan berbagai komponen sekolah. Salah satu caranya adalah dengan strategi pengelolaan kelas unggulan yang bisa membantu meningkatkan prestasi belajar siswa.

SMP Negeri 1 Turi Lamongan juga memperhatikan pengelolaan ruangan serta sarananya, dimana kelas unggulan mempunyai standar sarana sendiri yang harus dipenuhi. standar sarana yang ada di kelas unggulan tersebut diantaranya yaitu data siswa,data siswa masuk, data siswa absen, laptop, LCD, AC,dan kursi. Setiap hari sabtu SMP Negeri 1 Turi Lamongan melaksanakan program bimbingan belajar, bimbingan belajar di datangkan tutor dari luar sekolah SMP Negeri 1 Turi yang berjumlah 5 tutor, sementara itu selebihnya adalah dari guru dalam SMP Negeri 1 Turi Lamongan itu sendiri dan guru tersebut di seleksi. Sebelum melaksanakan Ujian Akhir Sekolah dan Ujian Kenaikan Kelas SMP Negeri 1 Turi Lamongan juga menyelenggarakan Ujian Kompetensi Unggulan yang dikhususkan untuk Kelas Unggulan, setelah Ujian Kompetensi Unggulan selesai, apabila ada siswa yang mendapatkan nilai tertinggi akan mendapatkan reward dan piagam nilai. Dan siswa yang tidak mendapatkan nilai tertinggi namun mendapatkan piagam nilai. SMP Negeri 1 Turi Lamongan juga menyelenggarakan kursus bahasa inggris di setiap liburan semester dan mendatangkan tutor dari pare Kediri.

Menurut Mulyasa (2006:25) strategi merupakan usaha yang dilakukan secara kontinyu, sistematis dan terkoordinasi yang tujuannya adalah meningkatkan kualitas pelayanan agar pelanggan atau konsumen mendapatkan manfaat yang maksimal. Sementara itu , strategi dijelaskan oleh Gaffar (2004:14) sebagai suatu rencana yang berisi langkah menyeluruh dan terintegrasi yang bisa menjadi pedoman dalam melakukan suatu pekerjaan, menjadi arah dalam mewujudkan tujuan dan bisa unggul dalam kompetisi. Strategi juga dijelaskan sebagai instrumen yang reliabel dalam arti bisa diandalkan untuk mengelola suatu hal, agar 
penggunanya tidak hanya bisa bertahan tetapi juga juga tumbuh dan berkembang dengan lebih baik dari sebelumnya. Berkaitan dengan pengajaran maka strategi pengajaran mengacu pada struktur, sistem, metode, teknik, prosedur, dan proses yang digunakan seorang guru selama pengajaran. Ini adalah strategi yang digunakan guru untuk membantu pembelajaran siswa.

Menurut Akdon (2007:14-17), strategi adalah proses tindakan untuk mencapai tujuan, oleh karena itu manajemen strategi dapat dijelaskan sebagai tindakan-tindakan yang dilakukan menurut tahapan yang sudah ditentukan sebagai berikut: (1) Formulasi strategi rumusan yang dibuat untuk melihat peluang, ancaman, kekuatan dan juga kelemahan dari sekolah yang digunakan dalam pengembangan rencana jangka panjang agar manajemen pengelolaan menjadi efektif dan efisien, (2) Pelaksanaan atau Implementasi Strategi, yaitu sebuah strategi harus dikembangkan secara wajar dan logika setelah dirumuskan agar bisa menghasilkan tindakan, (3) Evaluasi atau Pengendalian Strategi, tahap ini organisasi akan berfokus pada monitoring dan juga evaluasi pelaksanaan manajemen strategi, tujuannya adalah untuk mengoreksi dan memastikan bahwa strategi tersebut berjalan sebagaimana yang diinginkan.

Strategi yang sudah disusun harus dipastikan keberhasilannya, oleh karena itu para manajemen akan selalu memantau dan mengevaluasi semua strategi yang diimplementasikan. Ada beberapa petunjuk pelaksanaan strategi menurut Hatten (1996:26) agar strategi berhasil dijalankan yaitu: (1) Sebuah strategi sebaiknya konsisten dan tidak bertentangan dengan kondisi sekitarnya. Juga harus konsisten dengan perkembangan yang ada didalam masyarakat, mempunyai potensi yang baik untuk membantu tumbuh kembang suatu organisasi, (2) Antara satu strategi dengan strategi yang lain harus saling mendukung dan tidak boleh saling bertentangan, (3) Perlunya berfokus pada pengintegrasian semua sumber daya yang ada agar strategi menjadi efektif dan tidak memisahkan antara satu dengan yang lain. Menghindari persaingan yang tidak sehat dalam unit kerja, (4) Strategi harus fokus pada kekuatan dan bukan pada kelemahan, (5) Memperhatikan ketersediaan sumber daya yang ada dan memanfaatkannya secara maksimal. Karena strategi merupakan suatu proes maka sumber daya harus dilibatkan dalam setiap tahapan proses, (6) Resiko harus selalu diperhitungkan dalam membuat strategi untuk organisasi agar bisa dievaluasi dan dikontrol (7) Dasar untuk menyusun strategi adalah keberhasilan yang sudah dicapai, (8) Indikator dari keberhasilan suatu strategi dapat dilihat dengan adanya dukungan dari berbagai pihak relevan termasuk manajemen, pimpinan unit di dalam sebuah organisasi.

Strategi menurut Robbins dan Coulter (2010:137-139), semestinya bisa membantu mendukung tercapainya visi dan misi dari organisasi. Dalam implementasi strategi harus digunakan berbagai variasi strategi terbaik untuk bisa mencapai tujuan organisasi yang sudah ditentukan oleh organisasi.

Definisi dari manajemen menurut Terry (1997:14) adalah kegiatan yang dilakukan dengan melibatkan orang lain untuk mencapai tujuan yang telah ditetapkan. Sementara itu, pengertian dari manajemen menurut Stoner et. al. (2000:11) merupakan proses dari rencana, organisasi, kepemimpinan, dan monitoring dari anggota dan memanfaatkan sumber daya yang ada dalam rangka mencapai tujuan organisasi. Manajemen sebagai proses individual dan juga kelompok dijelaskan oleh Gibson dkk (2000:117) yang bertujuan untuk melakukan koordinasi untuk bermacam kegiatan dengan tujuan mencapai hasil yang hanya bisa diraih dengan kerjasama. Manajemen adalah gabungan dari berbagai usaha yang dilakukan untuk mendapatkan hasil dan mencapai tujuan yang sudah ditentukan dengan menggunakan sumber daya manusia yang tersedia.

Kelas unggulan dijelaskan oleh Silalahi (2006:01) sebagai kelas yang mengajarkan program-program spesifik untuk siswa yang termasuk unggulan dengan pengembangan bakat dan kreativitas yang ada didalam diri agar potensi yang ada bisa keluar dan bisa tumbuh dan berkembang sesuai dengan tingkat kecerdasan dan kemampuan siswa. Supriyono (2009:13) mengutip penjelasan dari departemen Pendidikan dan Kebudayaan Republik Indonesia mendefinisikan kelas unggulan sebagai suatu kelas yang dikembangkan untuk mencapai keunggulan dalam proses dan hasil pendidikan. Sementara itu menurut Direktorat Pendidikan Dasar kelas unggulan adalah kelas yang 
terdiri dari siswa yang mempunyai prestasi diatas rata-rata yang digabungkan dalam satu kelas dan mendapatkan pelajaran yang ditentukan secara khusus. Kelas unggulan merupakan kelas yang diperuntukkan secara spesifik bagi siswa yang mempunyai bakat, kemampuan, keahlian, kepintaran dan juga kreativitas yang lebih dari teman-temannya dan memperoleh pengajaran spesifik sehingga potensi yang ada didalam dirinya bisa lebih berkembang dengan baik menurut kurikulum yang berlaku.

Pemerintah Indonesia telah mendukung pengembangan kemampuan anak-anak yang berbakat ini dengan memberikan beasiswa. Namun untuk penyelenggaraan kelas unggulan, masih belum optimal. Karena masih banyak sekolah yang belum menerapkan program kelas unggulan di sekolahnya. Anak yang mempunyai kemampuan diatas rata-rata dan mempunyai tingkat intelegensi tinggi akan membutuhkan bimbingan yang maksimal agar ia bisa meningkatkan prestasi yang lebih baik. Beberapa kondisi yang sering ditemukan adalah siswa enggan untuk belajar karena model pembelajaran atau strategi pengajaran dikelas yang kurang menarik. Untuk mencegah hal itu terjadi terus menerus maka perlu dibuat kelas khusus unggulan untuk menyaring siswa-siswa yang berprestasi.

Tujuan dari pembentukan kelas unggulan menurut Silalahi (2006:21) adalah untuk: (1) Mendorong pengembangan dan peningkatan mutu pendidikan, (2) Menciptakan siswa berkualitas dan mempunyai daya saing tinggi, (3) Membantu peningkatan kemampuan dan ilmu untuk tenaga pengajar, (4) Meningkatkan potensi yang ada pada sekolah, (5) Membantu meningkatkan kemampuan SDM dalam hal berkompetisi dan bersaing dibidang pendidikan agar unggul dan kompetitif.

Karakteristik kelas unggulan sebagai berikut: (1) Unggul Potensi Siswa, (2) Unggul Kompetensi Guru, (3) Unggul Program Pembelajaran, (4) Unggul Sarana Prasarana, (5) Unggul Kemitraan, (6) Unggul Dukungan Dana. Langkah yang harus dilakukan dalam upaya mewujudkan kelas unggulan yaitu: (1) Penentuan visi, misi dan juga tujuan pembentukan kelas unggulan, (2) Manajemen peserta didik, (3) Strategi pengembangan layanan siswa, (4) Pengembangan pembelajaran, (5) Strategi pengembangan lingkungan belajar, (6) Manajemen sarana dan prasarana, (7) Pengelolaan guru, (8)
Pengembangan kurikulum. Prestasi belajar menurut Surya (2004:16) adalah pencapaian siswa dengan perubahan perilaku. Secara disadari atau tidak, siswa akan memperoleh perilaku yang baru dan positif serta fungsional. Prestasi sendiri kemudian dijelaskan lebih lanjut sebagai pencapaian dari semua aspek terkait yaitu kognitif, afektif , konatif dan juga motorik sebagai hasil dari pembelajaran. Menurut Purwanto (2009 :54) Perilaku akan berubah sesuai dengan proses belajar dan mengajar yang terwujud setelah perilaku berubah menjadi lebih positif menurut tujuan pendidikan. Hasil belajar yang didapatkan dan terwujud dalam diri siswa dalam bentuk bertambahnya pengetahuan, pengalaman dan juga tingkah laku yang menjadi lebih baik dapat dikatakan sebagai sebuah prestasi belajar.

Prestasi belajar adalah hasil dari dampak pembelajaran yang dibuktikan dengan nilai atau angka dalam bentuk pemahaman terhadap materi pelajaran dan pencapaian tujuan yang sudah ditentukan. Bentuk dari prestasi bisa sebagai peningkatan hasil tes, peningkatan kemampuan dalam bidang seni, komputer , kemampuan matematika, termasuk juga peningkatan dalam kedisiplinan, toleransi, hormat-menghormati, dan juga kepemimpinan serta bentuk lainnya. Menurut pengertian tersebut, dapat disimpulkan bahwa prestasi belajar adalah semua aspek kemampuan termasuk kemampuan kognitif, afektif dan psikomotorik yang mengalami perkembangan positif dihasilkan dari kegiatan belajar mengajar di kelas unggulan.

Faktor yang mempengaruhi berhasil atau tidaknya siswa dalam belajar yaitu faktor internal dan juga eksternal. Menurut Dalyono (2009:55) yang termasuk faktor internal dan eksternal adalah: (1) faktor internal yaitu aspek fisiologis dan aspek psikologis. Aspek fisiologis adalah Kesehatan tubuh dari siswa. Kesehatan bisa mempengaruhi siswa dalam menerima pelajaran. Sedangkan aspek psikologis yang dipengaruhi oleh intelegensi siswa, bakat dan fokus. (2) faktor eksternal yaitu faktor keluarga, sekolah dan masyarakat.

\section{METODE}

Penelitian menggunakan pendekatan kualitatif dengan jenis penelitian deskriptif (Sugiyono, 2017:8). Menurut Creswell 
(2009:52) Penelitian kualitatif adalah sarana untuk mengeksplorasi dan memahami makna individu atau kelompok yang merupakan masalah sosial. Penelitian ini dilaksanakan di Sekolah Menengah Pertama Negeri 1 Turi Lamongan yang beralamat di Jl. Raya Turi No. 164 kecamatan Turi, kabupaten Lamongan. Penelitian ini bertujuan untuk mendeskripsikan dan menganalisis Strategi Pengelolaan Kelas Unggulan dalam Meningkatkan Prestasi Belajar Siswa di SMP Negeri 1 Turi.

Pendekatan penelitian yang digunakan adalah kualitatif deskriptif dengan rancangan penelitian studi kasus (case study). Teknik pengumpulan data dilakukan dengan observasi, wawancara, dan studi dokumentasi. Teknik analisis data yang digunakan meliputi kondensasi data, penyajian data, dan penarikan kesimpulan (Miles dan Huberman, 2014:27). Uji keabsahan data dilakukan melalui uji kredibilitas yang mencakup triangulasi sumber, triangulasi teknik, triangulasi waktu, membercheck; uji validitas eksternal, dependabilitas, dan konfirmabilitas.

\section{HASIL PENELITIAN DAN PEMBAHASAN}

SMP Negeri 1 Turi Lamongan didirikan pada tahun 1983 dan berada di wilayah Kecamatan Turi Kota Lamongan provinsi Jawa Timur, memiliki Luas Lahan kurang lebih $14.590 \mathrm{M}^{2}$ di Jl. Raya Turi No. 164 kecamatan Turi Lamongan. Berdasarkan tabel dibawah ini dapat diketahui bahwa untuk 4 tahun terakhir jumlah peserta didik di SMP Negeri 1 Turi Lamongan mengalami kenaikan pada tahun 2015-2016, akan tetapi pada tahun 2018-2019 jumlah siswa lebih sedikit dari sebelumnya.

Tabel 1. Data Siswa (4 tahun terakhir)

\begin{tabular}{|c|c|c|c|c|c|c|c|c|c|}
\hline \multirow{2}{*}{$\begin{array}{c}\text { Th. } \\
\text { Pelajaran }\end{array}$} & \multirow{2}{*}{$\begin{array}{c}\text { Jml Pendaftar } \\
\text { (Cln Siswa } \\
\text { Baru) }\end{array}$} & \multicolumn{2}{|c|}{ Kelas VII } & \multicolumn{2}{|c|}{ Kelas VIII } & \multicolumn{2}{|c|}{ Kelas IX } & \multicolumn{2}{|c|}{$\begin{array}{c}\text { Jumlah } \\
\text { (Kls. VII + VII } \\
+ \text { IX) }\end{array}$} \\
\hline & & Jml Siswa & $\begin{array}{l}\text { Jumlah } \\
\text { Rombel }\end{array}$ & Jml Siswa & $\mid \begin{array}{c}\text { Jumlah } \\
\text { Rombel }\end{array}$ & Jml Siswa & $\begin{array}{l}\text { Jumlah } \\
\text { Rombel }\end{array}$ & Siswa & Rombel \\
\hline $2015 / 2016$ & 321 & 274 & 9 & 276 & 9 & 279 & 9 & 829 & 27 \\
\hline 2016/2017 & 313 & 292 & 9 & 289 & 9 & 274 & 9 & 855 & 27 \\
\hline 2017/2018 & 298 & 288 & 9 & 287 & 9 & 284 & 9 & 859 & 27 \\
\hline 2018/2019 & 238 & 238 & 8 & 283 & 9 & 284 & 9 & 805 & 26 \\
\hline
\end{tabular}

\section{Strategi Pengelolaan Kelas Unggulan Dalam Meningkatkan Prestasi Belajar Siswa SMP Negeri 1 Turi Lamongan.}

Strategi pengelolaan kelas dijelaskan sebagai pengorganisasian dan pengkoordinasian siswa untuk mencapai tujuan pendidikan. Pada proses ini siswa akan diseleksi dan juga akan dilakukan penyesuaian alat teknologi pendidikan. Pengelolaan kelas secara signifikan berkaitan dengan berhasil atau tidaknya proses belajar mengajar yang dilaksanakan. Salah satu cara yang dilakukan sekolah adalah dengan kegiatan remedial. Seperti halnya SMP Negeri 1 Turi bahwasannya sekolah memiliki strategi dalam pengelolaan kelas. Sekolah merupakan sarana yang sangat penting bagi berlangsungnya kegiatan belajar mengajar. Untuk itu, dibutuhkan strategi pengelolaan kelas yang baik agar kegiatan belajar mengajar dapat berjalan dengan baik dan tujuan pendidikan dapat tercapai. SMPN 1 Turi Lamongan memiliki beberapa strategi untuk pengelolaan kelas unggulan dalam meningkatkan prestasi belajar siswa yaitu antara lain membangun kerjasama dengan siswa dalam pembelajaran, menciptakan iklim pembelajaran yang kondusif, evaluasi proses belajar mengajar.

Menurut (Surya, 2004:16), Prestasi belajar adalah perubahan perilaku individu. Individu akan memperoleh perilaku yang baru, menetap, fungsional, positif, disadari dan sebagainya. Perubahan perilaku sebagai hasil pembelajaran. Hal yang sama dikemukakan oleh (Purwanto 2009:54) prestasi belajar adalah perubahan perilaku yang terjadi setelah mengikuti proses belajar mengajar sesuai dengan tujuan pendidikan. Dibawah ini akan dijelaskan strategi-strategi yang dimiliki oleh SMPN 1 Turi Lamongan Dalam Meningkatkan Prestasi Belajar Siswa, yakni:

Membangun Kerjasama dengan Siswa 


\section{dalam Pembelajaran}

Strategi pengelolaan kelas unggulan dalam meningkatkan prestasi belajar siswa di SMP Negeri 1 Turi Lamongan yang pertama ialah dengan membangun kerjasama dengan siswa dalam pembelajaran. Dalam dunia pendidikan, keterampilan kerja sama merupakan hal penting yang harus dilaksanakan dalam pembelajaran, baik di dalam maupun di luar sekolah. Kerjasama dapat mempercepat tujuan pembelajaran, sebab pada dasarnya suatu komunitas belajar selalu lebih baik hasilnya daripada beberapa individu yang belajar sendiri. Upaya dalam meningkatkan kerjasama dengan siswa tidaklah mudah. Menurut Yamin dan Ansari (2009:14) siswa memiliki perbedaan satu sama lain. Berbeda dalam minat, kemampuan kesenangan, pengalaman, dan cara belajar. Begitu juga berbeda dalam hal kerjasama. Strategi ini didukung oleh setiap guru. Setiap masuk kelas/mengajar guru melakukan presensi, Siswa yang hadir di sekolah dicatat oleh guru dalam buku presensi. Sementara siswa yang tidak hadir dicatat dalam buku absensi. Dengan perkataan lain, presensi adalah daftar kehadiran siswa, sementara absensi adalah buku daftar ketidakhadiran siswa. Begitu jam pertama dinyatakan masuk, para siswa masuk ke kelas dan guru mempresensi siswa satu persatu. Demikian juga pada jam-jam berikutnya setelah istirahat, guru perlu mempresensi kembali, barangkali ada siswa yang pulang sebelum waktunya. Tidak jarang, siswa pulang sebelum waktunya, hanya karena sudah dinyatakan masuk dengan presensi pada jam pertama. Pada umumnya ketidakhadiran siswa dapat dibagi kedalam tiga bagian: (1) alpa, yaitu ketidakhadiran tanpa keterangan yang jelas, dan alasan tidak bisa dipertanggungjawabkan; $\quad$ (2) ijin, ketidakhadiran dengan keterangan dan alasan tertentu yang bisa dipertanggungjawabkan, biasanya disertai surat pemberitahuan dari orang tua; dan (3) sakit, ketidakhadiran dengan alasan gangguan kesehatan, biasanya disertai surat pemberitahuan dari orang tua atau surat keterangan sakit dari dokter. Secara administratif, pengelolaan kehadiran dan ketidakhadiran siswa pada tingkat kelas menjadi tanggung jawab wali kelas. Oleh karena itu, wali kelas seyogyanya mendata secara akurat tingkat kehadiran siswa di kelas yang menjadi tanggung jawabnya sekaligus dapat menganalisis.

Mengajar didalam kelas menggunakan bahasa sederhana dan suara yang jelas. Suara adalah perubahan dari keras menjadi lemah, dan tinggi menjadi rendah, dari cepat menjadi lambat. Suara guru pada saat menjelaskan materi pelajaran hendaknya bervariasi, baik dalam intonasi, volume, nada dan kecepatan. Jika suara guru senantiasa keras terus atau terlalu keras, justru akan sulit diterima, karena siswa menganggap gurunya seorang yang kejam, bila sudah begitu siswa diliputi oleh rasa cemas, ketakutan selama belajar.

Materi selalu dikaitkan dalam kehidupan sehari-hari, artinya guru menjelaskan materi harus sesuai dengan pembelajaran atau mata pelajaran yang akan disampaikan. Pelajaran yang terpisah dari pengalaman sehari-hari, hanya akan didengar, dan tentu saja akan membuat siswa mudah lupa. Tetapi belajar sesuatu yang dapat kita lihat, apalagi sering dijumpai dalam hidup sehari-hari akan membuat kita ingat. Lebih-lebih ketika hal tersebut bisa dilakukan dan diaplikasikan sendiri, akan benar-benar membuat seorang pembelajar menjadi paham. Ketika proses belajar diangkat dari peristiwa sehari-hari, yang dijumpai di lingkungan sekolah atau lingkungan rumah maka akan membantu pembelajar memahami konsep yang riil. Selain itu dengan mengakrabkan diri belajar dari kehidupan sehari-hari, akan membuat pembelajar mengerti bagaimana mengaplikasikan apa yang telah dipelajarinya dan bagaimana menggunakannya untuk menghadapi permasalahan nyata di dalam kehidupan.

Guru menggunakan model pembelajaran yang bervariasi. Tujuan yang pertama agar setiap siswa memiliki beragam gaya belajar, metode mengajar tertentu hanya cocok untuk siswa yang memiliki gaya belajar tertentu. Jika guru hanya menggunakan satu macam metode, maka dapat dipastikan siswa yang memiliki gaya belajar tertentu akan menjadi bosan dan tidak dapat mencapai tujuan pembelajaran yang diharapkan. Tujuan kedua saat guru berusaha menggunakan bermacammacam metode mengajar dengan berbagai variasi, maka guru secara tidak langsung menjadi model yang memiliki jiwa kreatif. Kreativitas guru dan semangat yang terpancar pada saat mengajar dengan menggunakan 
berbagai variasi metode mengajar akan menjadi teladan bagi siswa. Siswa juga akan menjadi lebih kreatif. Siswa akan memiliki pemahaman yang mendalam.

Tujuan yang ketiga, penggunaan berbagai variasi metode mengajar yang sesuai dengan materi pembelajaran akan membuat siswa memililiki pemahaman yang lebih mendalam tentang materi tersebut. siswa tidak hanya sebagai manusia penghafal, tapi kemungkinan besar juga akan mampu mengaplikasikan pengetahuannya pada kehidupan nyata. Dengan hal tersebut siswa akan memiliki pengalaman belajar yang lebih

bermakna

Tujuan keempat, siswa akan terbantu mengekspresikan berbagai perasaan mereka saat guru menggunakan bermacam-macam metode mengajar. Mengekspresikan perasaan akan dapat siswa lakukan dengan berbagai cara, sebagai dampak dari penggunaan metode mengajar yang bervariasi. Ini akan membuat siswa mengikuti pembelajaran dengan sukarela dan bersemangat untuk berpartisipasi aktif. Mereka akan berpikir secara mandiri, dan secara tanpa sadar mereka telah tenggelam dan terlibat aktif dalam pembelajaran yang disampaikan guru.

\section{Menciptakan iklim Pembelajaran Yang Kondusif}

Strategi pengelolaan kelas unggulan dalam meningkatkan prestasi belajar siswa di SMP Negeri 1 Turi Lamongan yang kedua ialah dengan menciptakan iklim pembelajaran yang kondusif. Setiap guru berusaha menciptakan Suasana kelas yang aman dan nyaman. Banyak siswa yang merasa malu ketika ingin mengajukan pertanyaan, karena ia berasumsi bahwa ia akan ketahuan bodoh dan tidak paham pada materi pelajaran dan malu di hadapan teman-temannya. Oleh karena itu, guru harus bisa menggunakan strategi yang sesuai dan mampu memberikan rasa percaya diri kepada siswa agar berani mengungkapkan apa yang ada di benaknya. Sikap percaya diri harus dipupuk secara terus menerus agar siswa berani menghadapi resiko apapun yang akan muncul di kehidupan selanjutnya. Jika seorang siswa merasa malu dan tidak percaya diri untuk bertanya dan mengeluarkan pendapatnya maka ada kemungkinan pencapaian prestasinya menjadi terhambat. Langkah yang ketiga yaitu, memberikan waktu di lima menit terakhir proses belajar mengajar kepada siswa untuk bertanya tentang apa yang belum mereka pahami, dan juga meminta siswa merangkum dan menginterpretasikan apa yang sudah diajarkan secara singkat.

Bagilah menjadi dua pertanyaan besar, misalnya bagian mana yang paling berat dilakukan dan susah dimengerti. Pertanyaan selanjutnya, pengetahuan baru apa yang siswa dapatkan hari ini? Ini akan membuat siswa berdialog dengan dirinya sendiri mengenai proses belajar yang telah dilakukannya, yang keempat guru membiasakan budaya menjelaskan, bukan budaya asal menjawab dengan betul. Ciri-ciri sebuah pertanyaan yang baik adalah pertanyaannya hanya satu tetapi mempunyai jawaban beragam. Guru harus mengarahkan siswa agar berani berdebat atas pendapatnya namun dengan cara yang sopan dan santun. Langkah yang kelima yaitu memastikan siswa menjawab apakah ia yakin pada jawabannya atau tidak. Guru harus peka terhadap keberanian dan sikap yang ditunjukkan oleh siswanya.

\section{Evaluasi Proses Belajar Mengajar}

Evaluasi adalah suatu tahapan yang penting dan diperlukan karena dengan evaluasi perkembangan dan juga kemajuan siswa bisa diketahui. Setiap guru harus mengetahui hasil dari proses pembelajaran yang sudah dilaksanakan agar bisa menjadi panduan untuk melihat sejauh mana siswa mengerti dan memahami mata pelajaran dan apa yang harus dilakukan jika ada masalah dalam pelajaran tersebut. Perkembangan atau bahkan kemunduran prestasi siswa bisa diketahui melalui evaluasi yang dilakukan. Evaluasi pembelajaran dilakukan secara sistematis dengan melakukan pengumpulan, analisis dan juga interpretasi dari berbagai data dan informasi terkait agar bisa diketahui pencapaian yang sudah diperoleh.

Evaluasi proses pembelajaran adalah evaluasi yang mencakup kesesuaian antara proses pembelajaran dengan garisgaris besar program pembelajaran yang ditetapkan, kemampuan guru dalam melaksanakan proses pembelajaran, kemampuan siswa dalam mengikuti proses pembelajaran. Selain Membangun Kerjasama dengan Siswa dalam Pembelajaran, Menciptakan Iklim Pembelajaran yang 
Kondusif, strategi ketiga yang dilaksanakan dalam pengelolaan kelas unggulan dalam meningkatkan prestasi belajar siswa di SMPN 1 Turi adalah guru memberikan evaluasi proses belajar mengajar. pada awal pembelajaran guru akan melaksanakan pre tes begitu juga setelah selesai melaksanakan pembahasan materi akan diadakan post tes, melaksanakan ulangan harian dan pemberian tugas-tugas serta mengadakan ujian semester bersama.

\section{Faktor Pendukung dan Faktor Hambatan Strategi Pengelolaan Kelas Unggulan Dalam Meningkatkan Prestasi Belajar Siswa di SMP Negeri 1 Turi Lamongan.}

Faktor yang mendorong suatu pekerjaan agar berjalan lancar disebut sebagai faktor pendorong. Dalam strategi pengelolaan kelas ada faktor yang mendukung antara lain : faktor kurikulum, sarana, guru, siswa, keluarga. Nawawi (1989:116) berpendapat bahwa kurikulum, bangunan dan sarana, guru, murid, dan dinamika kelas merupakan faktor- faktor yang mendukung pengelolaan: (1) Kurikulum : Setiap sekolah memerlukan kurikulum. Sementara itu kurikulum tersebut harus sesuai dengan kebutuhan siswa yang makin kompleks dalam perkembangannya. Penentuan kurikulum akan memberikan pengaruh pada pencapaian prestasi siswa disebut sekolah. Sebuah kelas bukan hanya sebagai tempat siswa berkumpul untuk mempelajari sejumlah ilmu pengetahuan. Namun merupakan wadah untuk mendidik anak yang merupakan anggota masyarakat untuk bisa dikembangkan semua aspek intelektualitasnya agar bisa berkembang dengan baik. (2) Sarana Kelas: Setiap gedung dan ruangan yang dibangun harus sesuai dengan kebutuhan siswa. Tidak terlalu sempit dan bisa memfasilitasi siswa dalam belajar. Dibutuhkan kreativitas yang tinggi agar sekolah bisa menyesuaikan gedung yang tersedia dengan kebutuhan dan kurikulum sekolah yang berlaku secara nasional. (3) Guru: disini guru berperan sebagai pemimpin, yang memimpin siswa dikelas.

(4) Siswa: merupakan potensi kelas yang harus dimanfaatkan guru dalam mewujudkan proses belajar mengajar yang efektif. Murid adalah anak-anak yang sedang tumbuh dan berkembang, dan secara psikologis dalam rangka mencapai tujuan pendidikannya dengan lembaga pendidikan formal, khususnya berupa sekolah. Murid sebagai unsur kelas memiliki perasaan kebersamaan yang sangat penting artinya bagi terciptanya situasi kelas yang dinamis. Dalam strategi pengelolaan kelas akan ditemui berbagai faktor penghambat Hambatan tersebut bisa datang dari guru sendiri, dari peserta didik, lingkungan keluarga ataupun karena faktor fasilitas. (5) Fasilitas: faktor penting lainnya adalah upaya guru memaksimalkan programnya, fasilitas yang kurang lengkap akan menjadi kendala bagi seorang guru dalam beraktivitas dan memaksimalkan program pembelajarannya.

(6) Keluarga: Tingkah laku siswa di dalam kelas merupakan pencerminan keadaan keluarganya. Sikap otoriter orang tua akan tercermin dari tingkah laku peserta didik yang agresif dan apatis. Problem yang dihadapi guru memang banyak berasal dari lingkungan keluarga. Kebiasaan yang kurang baik di lingkungan keluarga seperti tidak tertib, tidak patuh pada disiplin, kebebasan yang berlebihan atau terlampau terkekang merupakan latar belakang yang menyebabkan siswa melanggar di kelas. (7) Siswa: siswa dalam kelas dapat dianggap sebagai seorang individu dalam suatu masyarakat kecil yaitu kelas dan sekolah. Mereka harus tahu haknya sebagai bagian dari satu kesatuan masyarakat disamping mereka juga harus tahu akan kewajibannya dan keharusan menghormati hak orang lain dan teman-teman sekelasnya.

Kurangnya kesadaran siswa dalam memenuhi tugas dan haknya sebagai anggota suatu kelas atau suatu sekolah merupakan faktor utama penyebab hambatan pengelolaan kelas. Oleh sebab itu, diperlukan kesadaran yang tinggi dari siswa akan hak serta kewajibannya dalam mengikuti kegiatan belajar mengajar. (8) Gaya guru yang monoton: Guru yang mengajar dengan cara yang monoton sudah pasti akan membuat siswa menjadi bosan. Metode pengajaran yang digunakan oleh guru sangat mempengaruhi sikap siswa terhadap pelajaran tersebut. Beberapa contoh misalnya penggunaan metode ceramah dalam mengajar, intonasi yang tidak menarik dan tidak jelas, serta tidak adanya feedback dari pelajaran bisa menyebabkan kebosanan pada siswa.

\section{Solusi Mengatasi Hambatan Strategi}




\section{Pengelolaan Kelas Unggulan Dalam Meningkatkan Prestasi Belajar Siswa di SMP Negeri 1 Turi Lamongan}

Guru bisa memaksimalkan program kelas unggulan walaupun sarana dan prasarana masih kurang memadai. Sebagai solusi untuk mengatasi masalah tersebut, guru harus mampu membuat program pembelajaran yang menarik dan sebisa mungkin tetap dapat memotivasi minat siswa untuk belajar agar prestasi siswa tidak terpengaruh dan permasalahan akan kurang memadainya sarana prasarana tidak menjadi penghambat keberhasilan siswa meraih prestasi. Siswa harus selalu sadar diri bahwa proses belajar mengajar ini akan sangat berguna bagi dirinya, sehingga jika pelajaran sedikit monoton tetap bersemangat. Sementara itu pada sisi guru yang mengajar solusinya harus bisa merubah suasana kelas menjadi yang menyenangkan, supaya siswa tidak bosan.

Pihak sekolah harus bisa memberikan pemecahan dan pengarahan yang baik ketika terjadi kendala atau hambatan terkait permasalahan kelas unggulan. Untuk mengapresiasi dan mendorong siswa maka pihak sekolah dapat memberikan reward atau hadiah kepada siswa yang mempunyai prestasi baik. Hal ini berguna agar siswa kelas unggulan termotivasi dan selalu bersemangat dalam meningkatkan prestasi belajarnya di sekolah.

Demikian pula masalah ketersediaan sarana dan prasarana yang semestinya harus memadai, selanjutnya agar siswa tidak ramai pada saat Kegiatan Belajar Mengajar guru memberikan sanksi yang tegas tujuannya agar siswa tidak mengulangi kesalahan dan agar tidak ditiru oleh siswa yang lain. Selanjutnya apabila guru mengajar dikelas gaya mengajarnya tidak monoton, guru memberikan pelajaran yang menantang dan variatif sehingga siswa dapat semakin bersemangat dan termotivasi untuk berpartisipasi secara aktif dalam proses belajar mengajar di kelas.

Pada saat pembelajaran, guru dapat memberi pembelajaran yang bervariasi seperti misalnya memberikan permainan di dalam kelas berupa simulasi ular tangga, hal ini bertujuan agar siswa tersebut lebih mempunyai wawasan lebih dalam,dan model tempat duduknya dirubah Letter $U$ tujuannya agar siswa dapat terfokus pandangannya ke depan pada saat guru menerangkan atau menjelaskan materi yang disampaikan.

\section{KESIMPULAN}

Berdasarkan hasil penelitian terdapat beberapa simpulan yang dapat diuraikan, sebagai berikut :

1. Strategi pengelolaan kelas yang baik diperlukan agar kegiatan belajar mengajar berjalan dengan baik dan tujuan pendidikan dapat tercapai. SMPN 1 Turi Lamongan memiliki beberapa strategi untuk pengelolaan kelas unggulan dalam meningkatkan prestasi belajar siswa yaitu dengan membangun kerjasama dengan siswa dalam pembelajaran, menciptakan iklim pembelajaran yang kondusif dan mengevaluasi hasil belajar.

2. Dalam strategi pengelolaan kelas ada faktor yang mendukung antara lain : faktor kurikulum, sarana, guru, siswa, keluarga. Kurikulum yang dipergunakan di sekolah sangat besar pengaruhnya terhadap aktivitas kelas dalam mewujudkan proses belajar mengajar yang berdaya guna bagi pembentukan pribadi siswa. Sarana Kelas, Perencanaan dalam membangun sebuah gedung untuk sebuah sekolah berkenaan dengan jumlah dan luas setiap ruangan, letak dan dekorasinya yang harus disesuaikan dengan kurikulum yang dipergunakan. Guru, Untuk itu peranan guru sangat menentukan karena kedudukannya sebagai pemimpin pendidikan diantara murid-murid dalam suatu kelas. Siswa, merupakan potensi kelas yang harus dimanfaatkan guru dalam mewujudkan proses belajar mengajar yang efektif. Dalam strategi pengelolaan kelas akan ditemui berbagai faktor penghambat yang bisa datang dari guru itu sendiri, dari peserta didik, lingkungan keluarga ataupun karena faktor fasilitas.

3. Solusi dalam mengatasi hambatan strategi pengelolaan kelas unggulan dalam meningkatkan prestasi belajar siswa adalah fasilitas yang kurang memadai guru harus memaksimalkan programnya,dan apabila ada faktor penghambat dari keluarga maka siswa perlu dibimbing yang baik dari keluarga, dan diperlukan kesadaran yang tinggi dari siswa akan hak dan kewajibannya dalam mengikuti kegiatan belajar mengajar, dan guru yang 
mengajar di kelas monoton seharusnya solusinya harus bisa merubah suasana kelas menjadi yang menyenangkan, supaya siswa tidak bosan.

\section{SARAN}

Guru bisa memaksimalkan program kelas unggulan walaupun sarana dan prasarananya kurang memadai. Seperti ketika mengajar dikelas gaya mengajarnya tidak monoton, guru memberikan pelajaran yang menantang dan variatif sehingga siswa makin bersemangat dan termotivasi untuk berpartisipasi secara aktif dalam proses belajar mengajar di kelas. Siswa harus selalu sadar diri bahwa proses belajar mengajar ini akan sangat berguna bagi dirinya, sehingga jika pelajaran sedikit monoton tetap bersemangat. Untuk pihak sekolah harus bisa memberikan pemecahan dan pengarahan yang baik ketika terjadi kendala atau hambatan terkait permasalahan kelas unggulan. Untuk mengapresiasi dan mendorong siswa maka pihak sekolah dapat memberikan reward atau hadiah kepada siswa yang mempunyai prestasi baik. Hal ini berguna agar siswa kelas unggulan termotivasi dan selalu bersemangat dalam meningkatkan prestasi belajarnya di sekolah. Demikian pula masalah ketersediaan sarana dan prasarana yang semestinya harus memadai.

\section{DAFTAR RUJUKAN}

Akdon, 2007. Strategic Management for Educational Management (Manajemen Strategik untuk Manajemen Pendidikan). Bandung : Alfabeta.

Creswell, John W. 2009. Research Design Pendekatan Penelitian Kualitatif. Yogyakarta : Pustaka Pelajar. Penterjemah Achmad Fawaid.

Dalyono, M. 2009. Psikologi Pendidikan. Jakarta : PT. Rineka Cipta.

Evertson, C. M. \& Weinstein, C. S. 2006. Research, practice, and contemporary issues. Handbook of Classroom Management. Mahwah, NJ : Larence Erlbaum Associates, Inc.

Gaffar, M.F. 2004. Membangun Kembali Pendidikan Nasional dengan Fokus :
Pembaharuan Manajemen Perguruan Tinggi pada Era Globalisasi. Surabaya : Makalah Konvensi Nasional Pendidikan Indonesia V, 5-9 Oktober 2004.

Gibson, John M. Ivancevich., dan James H. Donnelly Jr. 2000. Organizations : Behaviour, Structure and Process. New York : Prentice Hall.

Hatten, K. J. and Hatten, M. L. 1996 "Strategic Groups, Asymmetrical Mobility Barriers, and Contestability," Strategic Management Journal. United States of America : Elsevier Inc.

Marzano, R. J. 2003. What Works in Schools. Translating Research into Action. Alexandria, VA : Association for Supervision and Curriculum Development (ASCD).

Miles, M.B., Huberman, A.M., dan Saldana, J. 2014. Qualitative Data Analysis, A Methods Sourcebook, $3^{\text {th }}$ Edition. USA : Sage Publications. Terjemahan Tjetjep Rohindi Rohidi, UI-Press.

Mulyasa, 2006. Manajemen Berbasis Sekolah. Bandung : PT Remaja Rosdakarya.

Nawawi, Hadari. 1989. Organisasi Sekolah dan Pengelolaan Kelas. Jakarta : PT Haji Mas Agung.

Purwanto, Ngalim. 2009. IImu Pendidikan Teori dan Praktis. Bandung : PT. Remaja Rosdakarya.

Robbins, Stephen P., dan Coulter, Mary. 2010. Manajemen. Edisi Kesepuluh. Jakarta : penerbit Erlangga.

Silalahi, Arifin. 2006. Program Kelas Unggulan, http://digilib.unila.ac.id/724/3/BAB\%20 11.PDF, diakses pada Mei 2019.

Stoner, James A. F., Freeman dan Gilbert. 2000. Manajemen. Alih Bahasa Wilhelmus W. Bakowatun dan Benyamin Molan. Jakarta : Intermedia.

Sugiyono. 2017. Metode Penelitian Kombinasi (Mixed Methods). Bandung : Alfabeta.

Supriyono, Agus. 2009. Penyelenggaraan Kelas Unggulan di SMA Negeri 2 Ngawi. Tesis. Surakarta : Universitas 
Sebelas Maret

Surya, Mohammad. 2004. Psikologi Pembelajaran dan Pengajaran. Bandung : Pustaka Bani Quraisy.

Syaodih, Nana Sukmadinata. 2003. Landasan Psikologi Proses Pendidikan. Bandung : Remaja Rosdakarya.

Terry, George R. 1997. Principle of Management. New Work : Richard D. Irwin, Inc.

Yamin, M dan Ansari, B.I. 2009. Teknik Mengembangkan Individual Siswa. Jakarta : Gaung Persada Press.

Wubbels, T., Brekelmans, M., Van Tartwijk, J., \& Admiraal, W. 1999. Interpersonal relationships between teachers and students in the classroom. In H.C. Waxman \& H.J. Walberg (Eds.), New directions for teaching practice and research (pp. 151-170). Berkeley, CA : McCutchan. 